\title{
Ethics as a true revolution, another way to read Levinas or beyond ${ }^{1}$ Ética como verdadeira revolução: Outra maneira de ler Levinas ou além
}

Esteban J. Beltrán Ulate
Ricardo Timm de Souza

\begin{abstract}
This paper criticizes social revolution, by focusing on the reconfiguration of the notion from an ethical point of view. It is divided in three sections: (i) Brother's death; (ii) Remove the sandals; (iii) Thou wilt be as many as the stars. Each section contains Levinas's thought as the main axis. Although it is well known that Levinas does not develop a theory of revolution, it is possible to find a fruitful analysis in light of his meditations about politics and ethics.
\end{abstract}

Keywords: ethics, Levinas, Otherness, Politics, Revolution

Resumo: Este artigo critica a revolução social, concentrando-se na reconfiguração da noção de um ponto de vista ético. Está dividido em três seções: (i) a morte do irmão; (ii) Remova as sandálias; (iii) Serás tantas quantas são as estrelas. Cada seção contém o pensamento de Levinas como o eixo principal. Embora seja bem sabido que Levinas não desenvolve uma teoria da revolução, é possível encontrar uma análise frutífera à luz de suas meditações sobre política e ética.

Palavras-Chave: Alteridade, Ética, Levinas, Política, Revolução

\section{Introduction}

Revolution is dead, it is a worn-out concept. Revolutionary project has failed in its main thesis, because death cannot be the key to build a new civilization. The task of the present study is to leave aside the collapse

\footnotetext{
${ }^{1}$ The work of revising the text in English by Mabel Villalta, (MBA, BA in English Teaching and Translation), is gratefully acknowledged.

2 Member of the Costa Rican Philosophy Association (ACOFI), Latin American Circle of Phenomenology (CLAFEN), Coordinator of the Institute of Research in Jewish Philosophy (IIFJ), is currently pursuing a master's degree in Philosophy at the University of Costa Rica. <esteban.beltran@ucr.ac.cr>

${ }^{3}$ PPGFILO/PUCRS < timmsouz@pucrs.br>.
} 
of the concept and to construct a new understanding of revolution as ethics, from a levinasian perspective.

This paper criticizes social revolution, and focuses on the reconfiguration of the notion from an ethical point of view. It is divided in three sections: (i) Brother's death; (ii) Remove the sandals; (iii) Thou will be as many as the stars. Each section contains Levinas's thought as the main axis. Although it is well known that Levinas does not develop a theory of revolution, in his meditations about politics and ethics, it is possible to find a fruitful analysis.

From ancient times, the concept of revolution has been linked to political aspects. Aristotle, in Politics, ${ }^{4}$ refers to the context of the constitution. Later, the concept emerges in modern age, in the middle of the rising nations, and in contrast to monarchy and tyrannical systems. Some well-known, are: the English, French, Bolshevik, Xinhai and Cuban revolutions, amongst other. However, these movements were consecrated from the death of the other. The revolution that cries for freedom ends up washing its hands with the blood of their brothers, in its lies and deceit.

False revolution has taken root since the death of the neighbor; the ideals of justice and freedom have been truncated by non-recognition of the other. The despair of the masses triggers a marked action of aggression, which becomes war. The vicious circle of war will not end with this conception of revolution. Vladimir Lenin is mistaken in assuming that only after the downfall, overthrow and expropriation of the bourgeoisie, the end of wars will be a reality. ${ }^{5}$

As a military movement, revolution uses violence to destroy, to show the human condition of selfishness, the neglect of the other and the treatment of others as objects. Humans are only artifacts in front of the selfish ego blinded by a false ideal of freedom, who can breach the mandate of: "Thou will not kill".

History shows, with blood, the atrocities of revolutionary projects that fought for humanity against humanity, Levinas' words are still valid: "Today's anxiety is more profound. It comes from the experience of revolutions that sink into bureaucracy and repression, and totalitarian

\footnotetext{
${ }^{4}$ Aristot. Pol. 2.1262b.

${ }^{5}$ Lenin, V. (1979). El programa militar de la Revolución Proletaria, (write in german in 1916, published in 1917) present in V.I. Lenin Obras Escogidas (1979), p.79o.
} 
violence that pass as revolutions". ${ }^{6}$ Revolutions of the masses provoke hunger, hatred and death; it is the hopelessness that has clouded the eyes and do not allow to see the brother. It is true that a necessity for change is behind the movement, but this necessity does not justify the aggression against humanity.

A dehumanized humanity forgets its children in the room and leaves them to die alone, as mentioned in Gregory in Kafka's text. ${ }^{7}$ Today, the world is invaded by a silence while the corps of the immigrants, who tried to cross the Mediterranean Sea, leave their mark in the memory of the beaches that are now cemeteries. There are those who cling to the idea of revolution of 1789 , and feed the dream of harvesting liberties through blood. Others propose a revolution through the political apparatus; Antoine de Saint-Exupéry glimpses brightly, with a baobab idea, ${ }^{8}$ how political systems can lead to destruction. After the twentieth century, humanity dwells in fear, with an allergic reaction towards one another.

Ernesto Guevara de la Serna in a text entitle "Un pecado de la revolución”, manifests that revolutions are radical and accelerated social transformations, almost never foreseen and founded on passions and improvisation. This is part of their imperfect condition, since they are never perfect, as Guevara said. ${ }^{9}$ This study will not assume the revision to respond to the sin of revolution beyond an analysis of the structural problems of the revolutionary program. The task at hand is to abandon the idea of revolution as ruin, as understood until this day.

The crime and allergic reaction towards the other are properties of the condition of iniquity inherent in every revolution. History reveals that revolution is not a simple revolt, or a simple overlapping of one paradigm over another with the approval of several specialists. Revolutions are embodied in the ruthless death of the other, to obtain a reward. It is not possible to achieve freedom through the death of the other as it is not possible to build the kingdom from the death of the neighbor.

\footnotetext{
${ }^{6}$ No identity, in Collected Philosophical Papers, of Emmanuel Levinas, translated by Alphonso Lingis, p. 143

${ }^{7}$ Die Verwandlung

${ }^{8}$ Le Petit Prince

${ }^{9}$ Guevara (1980)
} 
The following section explores the properties of crime, in order to understand the atrocity of revolution. It focuses on the utilitarian conception of the human being who lives in solitude and disposes of his neighbor as an object, within the framework of a political-economic dynamic, which accentuates the allergic reaction or alienation of the human.

\section{Brother's death}

False revolution has many faces; crime is one of them. Crime is an inherent element in the structure of the revolution, and has its own logic, presents itself as irruption, breaks the flow of natural existence, causes trembling and fear.

Thanks to crime, circumstances are altered and reflection is turned on the event. It causes suffering, and the situation lacking content is evident. Irreversibility appears as an intuition; before this phenomenon that clouds the comprehensive horizon of reason; words lose their condition as a mechanism of formal expression of ideas; words are insufficient. $^{10}$

The irreversibility of the crime terrifies. Time is split by an event that cannot be erased. The event is unforgettable, even in memory it is challenged itself, by the inevitable and irreversible crime. The event occurs abruptly, a collapsed existential singularity that extends; a symptom that communicates in an "intropathy" (Einfühlung) ${ }^{11}$ way, ramifying the experience of the irreversible, inevitable and unforgettable.

Crime awakens anguish, and an overwhelming existence; the anguish of being affected, but even more the anguish of seeing its own face reflected in the face of the criminal. Crime confronts us with the limitless experience of hopelessness; the absurd relief of existence that was discovered in the world alone. The existence that, looking at itself thrown in the world, trembles at the totality that overwhelms it; crime is a blindness of hope, it is blindness to others.

The criminal does not contain the crime; therefore, the criminal can never amend the crime, much less reverse history and heal the breach. As

\footnotetext{
${ }^{10}$ Beltrán (2016a)

${ }^{11}$ Calcagno (2016)
} 
the crime cannot be forgotten, the event is unforgettable. The criminal will never be able to compensate the fault. Crime is not healed through crime; others who suffer before the irreversible, inevitable and unforgettable crime do not quench their thirst by sacrificing the criminal as immolating the criminal is embodying its face in a new crime; and produces loneliness.

Revolution is not a movement of ideals. It is a movement of hunger and hatred. Revolution updates as war, and war as crime. War evidences the condition of a hypocrite civilization, ${ }^{12}$ and crime evidences the condition of the allergic reaction towards the other. Today human beings have become the executioners of humanity; the global crisis is not an economic, food, real estate, or nuclear crisis; the current crisis is human. It is the diminution of the human being into merchandise. ${ }^{13}$ The present time shows the reduction of the man and the woman into a thing that favors a society without faces, with anonymous beings, where violence is present with a greater force, according to the needs of the prevailing ideologies. ${ }^{14}$

In the twenty-first century, new conceptions of revolution have appeared wrapped in new clothes within the framework of democratic schemes. However, the same history has been charged with revealing the logic of iniquity present in them. A specific case is the one lived in Venezuela, within the dynamics of the so-called Bolivarian revolution, which has taken human lives and coupled with a series of conflicts between citizens. The false revolution has many mutations, it can take new forms, but its content is the same. The iniquity that inhabits it, is indissoluble.

Levinas offers a reading that illuminates the understanding of the individual who embodies the revolution, starting with an interpretation of the self in solitude, of being hypostatized, revealed in Time et Autre (1979). First, we must start from the idea that the social revolution, as it is understood today, is the clearest manifestation of hope that arises from the hopelessness before the oppression of the other. Capital sin, however, lies in the fact that this revolt - the other oppressed - causes a change in

\footnotetext{
12 "l'évidence de la guerre se maintient dans une civilisation essentiellement hypocrite" Levinas (1971, p.9)

${ }^{13}$ Beltrán (2011)

${ }^{14}$ Beltrán (2016)
} 
the dynamics of power and becomes the oppressor of its former oppressor. A sort of Hegelian dynamics, of the master-slave, seems to follow from this situation. From a levinasian approach, the other-oppressed, driven by hunger and hatred, becomes the executioner of his oppressor, who is now another-oppressed.

Revolution is the revolt of the oppressed who becomes oppressor, and can kill his brother. In this iniquitous dynamic, crime is the daily bread; the angel of death touches the doors of each house in search of the firstborn. And the voice that asks for the other, finds the voice of the revolutionary man saying: Am I the guardian of the other?

The false revolution is the movement of the other-oppressed who seeks to take justice into his hands; a false justice, in his eagerness for freedom. He eclipses the others' gaze, and breaks the command of not to kill. In this understanding of false revolution, man is an existent in solitude that disposes of the world at his whim; everything else, even his peers are only artifacts in his service. The subject cast himself, does not know the feminine, nor the paternal. It is rooted to the ground, and does not think about the son. This being assumes death as any subject is assumed, as an artifact. $^{15}$

Surrender to death is a condition of the false revolution. However, during desert, in the loneliness of the subject, in the darkest and longest night, it manifests itself, not as a soliloquy of the soul with itself, but as presence itself, within the voice of the eternal. The voice of the eternal, manifests itself intangible, striking the door of egology, bursting into the architecture of reason, vibrating the fibers of feelings. It is the voice of the alterity, as Levinas indicates "L'altérité d'autrui est la pointe extreme du tu ne commettras pas d'homicide-" 16

This is the primordial event, the proto-aesthesis ${ }^{17}$ advent. It is a manifestation that breaks the synchronous look of time; it is a diachronic trace. In the face of the loneliness of the man who is about to sacrifice his neighbor, the angel's hand appears, who snatches the iniquitous weapon, and disturbs the man. The revolutionary man, manly subject, capable of answering for himself, is interpellated in the intimacy of his being. The

\footnotetext{
${ }^{15}$ Levinas (1979)

${ }^{16}$ Levinas in De l'Un a l'Autre present in Entre Nous, essais sur le penser-a-l'autre (1991)

${ }^{17}$ A re-reading of the concept of proto-aesthesis elaborated by Franz Brentano, Brentano (1988)
} 
man's gaze is not the same, he now collapses all his purpose, in front of the ruins of his story, with his eyes bulging; only one answer is possible, a "here I am".

This voice of the desert, is the alterity itself that takes the feminine. It is not the idea that reaches the outside of itself, it is a movement against the grain. Consciousness does not matter at this moment with an active function. The false revolution is questioned, in the depths of its bases, because the appearance is before ideology. It is a presence before any idea. This appearance confronts the other, as another. It reveals the world not as a place full of utensils but as a place with food. ${ }^{18}$

The man questioned by otherness, in the intimacy of the feminine, is perceived as a father, with the responsibility to procreate, to give birth, to surrender. But, this response demands a discovery of the feet, and to start a new walk. This new walk is ethical and political; otherwise, what is in question is man's own humanity. ${ }^{19}$

\section{Leave the sandals}

Some thinkers have intuited, a renewal in the content of the notion of revolution, such as Charles Peguy and Emmanuel Mounier. Charles Peguy was close to the idea of revolution. In a study, he assumes that "the revolution will be moral or else it will not be". ${ }^{20}$ Alternatively, Emmanuel Mounier, launches the sentence "the moral revolution will be economic or will not be. The economic revolution will be moral or will not be". ${ }^{21}$

Despite Peguy's and Mounier ${ }^{22}$ interest in providing a second reading on the notion of revolution, they leave open two perspectives on the different visions of violence. This demands an in-depth study that

\footnotetext{
${ }^{18}$ Levinas (1979)

${ }^{19}$ Levinas (1990)

${ }^{20}$ Peguy cited by Davies and Garffit (2014, p.41)

21 "Qué es el personalismo", in Mounier (1990)

${ }^{22}$ A passage that shows this tension is discovered in: "Allí donde no hay elección más que entre cobardía y violencia, yo aconsejaría la violencia...Si amamos la paz sólo por el temor a las bayonetas, prefiero que nos degollemos entre nosotros. Prefiero todavía ver exteriorizarse la violencia a verla reprimida por el miedo". Mounier (2007, p. 91), ("Where there is no choice between cowardice and violence, I would advise violence ... If we love peace only because of the fear of bayonets, I prefer that we slaughter ourselves among ourselves. I still prefer to see violence externalized to see it repressed by fear." Trad. Author).
} 
does not compel the present paper. A collaborative study would be essential to distinguish the boundaries between violence and the ideas of revolution they pose.

What does it mean to take off the sandals? It means to recognize the sacred land, to eradicate the idea of land as a support, as a possibility of possession. Removing the sandals implies an acceptance of the radical alterity that surpasses me; an otherness that calls me and at the same time rejects me. The trace that manages to throw the rider from the horse and summons him in the intimate. It is the trace of the infinite responsibility, that demands an ethical and political treatment. It is an enigmatic epiphany, as Lazlo Tangelyi explains "The face manifests itself face-to-face, but it manifests itself without manifesting itself; it resists being reduced to just a face ... this trace to an 'irreversible, immemorial and nonrepresentable past,' to a past 'absolutely elapsed'"23.

This call is not given by way of reason, but anticipates every idea. It is aesthetic, because its appearance is prior to any representation or fantasy. It emerges from the living body and seeps through the cracks of rationality. It is prior to the time of the hypostasis; it is contrary to the time of Il $y$ a; it happens as a tearing of the synchronous character. From an internal, autrui becomes present, in a messianic time. Andrew Kelly exemplifies this as fallows "the wholly or absolute other is something 'exterior to' or beyond me, namely other (autrui), which, as the face, calls me into question". ${ }^{24}$ This question is fundamental in the new concept of revolution.

The discussion on the inner revolution, whether moral according to Peguy, or "Metanoéte" 25 according to Mounier, requires a treatment in the intimacy of its gestation. It is here that the work of Levinas has a fruitful field of analysis. It is necessary to understand that this task is an action against the grain, recovering the echoes of the sacred.

\footnotetext{
${ }^{23}$ Tangelyi in Experience of Infinity in Levinas, present in Levinas Studies, Vol. 4, 2009, p. 119

${ }^{24}$ Kelly in Jankélévitch and Levinas on the "Wholly Other", present in Levinas Studies, Vol. 8, 2013, p. 31

${ }^{25}$ Metanoéte is, following a Xose Manuel Dominguez: "'Se trata de un cambio del corazón, en el que se dejan los antiguos valores, no arraigados en la persona, y se opta por los que hacen crecer a la persona. Este es el primer paso de la revolución personal: la conversion... " Domínguez, Calvo y Narvarte (2002, pp. 44-45), ("It is a change of heart, in which the old values are left, not rooted in the person, and opting for those who make the person grow. This is the first step of personal revolution: conversion... The only radical conversion is personal conversion", trad. author)
} 
It is important to emphasize that the manifestation of visage does not imply action taking on the part of the one who is questioned, since this presence can evoke fear and tremble. An opposed way can happen, as described by Buber when he characterizes the Eclipse of God. ${ }^{26}$ The first man is everyone who is challenged in intimacy, where the modesty emerges. The itinerary of Levinas allows us to interpret the possibility of flight or acceptance, in this appearance of the Visage.

It is fundamental to be clear that acceptance is not a primary but, rather, a secondary act. Before the visit of the other, the responsibility does not emerge as a decision of the Self. True revolution is not a heroic action, it is a passive disposition, it is not the exercise of the free self, vis-a-vis the other, but rather the inescapable protention of an immemorial memory. Levinas illuminates this situation as follows, "La responsabilité pour autrui ne peut avoir commencé dans mon engagement, dans ma décision”. ${ }^{27}$ Responsibility is a mandate that comes diachronic, moving contrary to the intentional conscience. This paradox, is the obligation that demands an action, a decision, and a word.

The one who flees, is doomed to artifacts, to be a being thrown into the world, living, waiting for his death, with the voices of the death of others. On the other hand, he who does not flee before the truth, paraphrasing Patocka's idea "to return to things themselves means: do not run away, do not sneak at the problem of truth". ${ }^{28}$ In the context of this discourse, the thing itself is beyond finitude. Man, patiently sees death, but his gaze does not end in finitude, but in transcendence through the relationship with the Other.

This exit from the hypostasis, like the exit of Ur of Chaldea, is without pretension to return. It is the opening, hospitable in front of the arrival of the other, that allows me to understand myself as a being in relation, not as a being in solitude. Life in relationship, is the building of the kingdom. It is a path from alterity to intimacy, and from intimacy to fecundity. The feminine is fertilized intimately, and the birth of the son implies transcendence, always ethical, in the other, that is not me but that

\footnotetext{
${ }^{26}$ Buber (2003)

${ }^{27}$ Levinas (1978, p. 24)

${ }^{28}$ Patocka, Introducción a la Fenomenología, "volver a las cosas mismas significa: no huir, no escabullirse ante el problema de la verdad" (2005, p. 65).
} 
is not without me and I am not without him. Levinas states that "The proximity of the other showing me his or her face, in society with me, and the implications of that encounter, overturns the logical and ontological play of the same and the other transforming it into ethics". ${ }^{29}$

The true revolution is ethical, is diachronic. It appears in front of the eyes as past in the instant of the present; it is an event that constituted itself as life word. It is a commitment that deformalizes time, voice resounding -Dire-, as a promise in the face of the other. In the gaze, the mystery, which is an event, it becomes a teacher. The event produces the suspension of the natural world; where is the rest? Only the resonance, the promise inscribed, now, in the memory, there is no need for anything else. The event, suspends history, is a fact that challenges the self to the point of removing it from reality, or rather, of causing the reality of the event to emerge, which cracks the temporal and the spatial. ${ }^{30}$ This act of total intimacy is personal, immediate, internal. How to get out of this intimacy? The only answer is with the eyes of the true revolutionary.

Like Moses, when he came down from the mountain, after having heard the voice that cried from above (autrui), the new revolutionary man is not the one who takes justice into his hands, but the one who lets himself be visited by justice itself, in an erotic act from the passivity of waiting. The revolution is not the action but the passion, with which it opens the eyes before the presence that cries out: "liberate my people".

Revolutionary awakening is intimately ethical, erected before all logic, ontology, or other edifice of reason. The revolutionary turn is gestated in the intimacy, there in the feminine. Levinas illuminates this idea by indicating, "La responsabilité pour Autrui - dans son antériorité par rapport à ma liberté dans son antériorité par rapport au présent et à la représentation est une passivité plus passive que toute passivité". ${ }^{31}$

Responsibility for the Other - in its anteriority to my freedom in its anteriority to the present and to the representation is a more passive passivity than any passivity" . This new way involves taking off the sandals, and embracing the new revolutionary project of extending through the nations and being as many, as the stars. A new civilization

\footnotetext{
${ }^{29}$ Alterity and Transcendence present in Levinas (1999, p. 76).

${ }^{30}$ Beltrán (2016b)

${ }^{31}$ Levinas (1978, p. 31)
} 
with the resonance of responsibility on the lips, with the caress of infinity in the eyes.

The true revolutionary does not leave only his neighbor before the mystery of death, "The proximity of the neighbor -the peace of proximityis the responsibility of the I for the other; the impossibility of leaving him alone before the mystery of death". ${ }^{32}$ This responsibility to the neighbor and to the community is non-transferable, "My responsibility is nontransferable, no one could replace me", 33 the human being who achieves dis-enchantment recognizes himself responsible. The political action is inescapable.

\section{Will be as many as the stars}

The visitation of the other, which takes place in the middle of the night, prior to any possibility; the ego derives as host; hospitality is demanded, the action that takes place before the presence of that other is inevitable. The call of the face, which is manifested and hidden, demands a response, prior to any decision, the "Here I am", anticipates the intentional consciousness. In this lies the real and true revolution.

Revolution, under the new approach that is intended to be demonstrated in this study, is not an heroic act, nor is it the mobilization in favor of a series of ideals, let alone a simple movement of the masses encouraged by hunger and cold. The true revolution is a total, radical revolt, from being hypostatized, to being-for-the-other.

This revolution anticipates the reason, it is placed in the intimacy, and bursts the chronological time. It is engendered in the most passive passivity of all. Responsibility precedes existence, and this responsibility assumes a task of meaning in the world. Before the truth, which cannot be fled, the truth of the other; the task that mankind assumes is to watch over the human condition.

New philosophies with the optics of hitlerianism appear; the revolution from the reading of Levinas, should not be understood from the elaboration of a dogmatic body of theories or ideologies saturated with a language that refers to the other as the foundation of a party line or mass

\footnotetext{
${ }^{32}$ Peace and Proximity, present in Levinas (1999, p. 141).

${ }^{33}$ Levinas (1985, p. 100)
} 
mobilizing project. The true revolution, from the levinasian point of view, understands that revolution is "pre-originating", and therefore every action of the free self, responds to a pre-sensibility, which is pre-free, anarchic.

From the "Here I am" to the community that anticipates the kingdom, this sentence must be the main axis that allows an understanding of the revolutionary route. The experience that surpasses the simple being in the world and by means of the encounter of the one with the others, passing, in an anticipated way, to the truth of the mandate. Justice is not the result of the virile Self, but it is derived from this passive, pre-originating synthesis.

The revolution, seen from this new approach, is not a mobilization, which will give way to a perfect state, from one moment to another. It is not the establishment of a new political order. This way of understanding revolution, is directed from the intimate to the community, including this as an area of relationships. The revolutionary task is understood as faceto-face, encouraging the truth of the mandate, and before the sentence of "Do not kill," it assumes the task of living to death with the other and the other. The revolutionary task is not of this time, it is prior to all times and, in turn, inscribed in all times; its character is diachronic, its dynamics are now and never.

Revolution is prior to language and is explored through language. Romano indicates that "The intelligence of language is in close continuity with a pre-linguistic intelligence inherent in our experience of the world itself" ${ }^{34}$ From a levinasian perspective, there is a language that tries to reconstruct the echoes of the pre-original presence, takes the trace (protoaesthetic) and caresses it with language. It is possible to have an experience prior to an experience of the world itself.

Revolution is an unexplored erotic dynamic, which makes man and woman the favorite lovers of humanity, who must give their life as an act of brotherhood. Not to give up life for another, not to die for the other, but rather, to live with and for the other. The revolutionary community is not confined to a nation, a territory, much less a land. The call comes from the most distant and most intimate. The mandate calls to grow from

${ }^{34}$ Romano (2015). 
generation to generation as the stars. This vocation is an ethical vocation, it is the task of the man and woman that reveal the true revolution.

The revolutionary community, should not be understood as a nation that lives like a glass bubble, or behind iron walls. The true revolutionary community is a meeting of peace. As expressed by Michael Morgan, in a study on the political ethics of Levinas, "Peace refers to the relationship the self has with the other to whom and for whom it is responsible. The peace of human relatedness". ${ }^{35}$ From this approach the strengthening of relationships is the key to the constitution of a new civilization.

The revolutionary man and woman, are far from the crime, since justice is not fulfilled in their hands, but is described by the word from a previous mandate. Justice is not objectively constructed in this preestablishment. Revolutionary life, from this perspective, involves a triad of: hospitality, food and blessing. In the face of the other, hospitality is the first unconditional condition, and in social life, the revolutionary task must not allow itself to be displaced by other people, much less annihilated. As far as food is concerned, the world is not composed of artifacts for a simple use by the "I", as mentioned above, following Levinas in Temps et Autre, the world is at hand. Food, this implies, beyond the utilitarian character, society is built in the encounter of food, in the breaking of bread, because the face-to-face commits each one to the rest. Regarding blessing, as a prayer that manifests to the goodness of the gift, it reveals the condition of being visited, in the presence-absence of the other. It is an act of gratitude and waiting, in life in community; the blessing is the infinite song that appears and hides in the face of the other that visited, of which we have no news, but we cannot stop thinking. Then its presence was before all thought and it comes in everyone as diachrony.

The revolution is pre-original; a gift in passivity. It is an erotic act that, from the unfathomable, remains touching the door of the present. We are condemned to the answer, the here is the answer par excellence. This true revolution is ethical first. The old revolution is a contempt for the human; it focuses on crime as false justice, which is nothing more than the show of an allergic reaction towards the other. The true revolution is prior to all freedom, therefore, we are condemned to responsibility, sweet 
E. Ulate; R. Souza - Ethics as a true revolution, another way to read Levinas or beyond | 85

condemnation which makes us say yes to the suffering of the other, to their pain, to their love; for in the other is inscribed the mystery of the other way of being or beyond the essence.

\section{Reference}

Aristotle. Aristotle in 23 Volumes, Vol. 21, translated by H. Rackham. Cambridge, MA, Harvard University Press; London, William Heinemann Ltd. 1944. In Perseus Digital

Library http://data.perseus.org/citations/urn:cts:greekLit:tlgoo86.tlg035.perseuseng1:2.1262b

Beltrán, Esteban (2016). Revolución personalista y comunitaria: una propuesta frente al falso pacifismo, expresión de violencia estructural. Invenio, Junio-Sin mes, 35-42, Argentina.

Beltrán, Esteban (2016a). Crimen: Lo irreversible, lo inevitable y lo indudable. Jueves 3 de marzo, 2016, Opinión, Diario Prensa Libre, Costa Rica.

Beltrán, Esteban (2016b). Meditaciones filosóficas a partir de "David vencedor de Goliat" de Caravaggio. Conference in Cultural Center of Spain in Costa Rica. Oct 27, 2016.

Beltrán, Esteban (2011). La muerte del otro. Miércoles 30 de marzo, 2011, Opinión, Semanario Universidad de Costa Rica, Costa Rica.

Bloechl, Jeffrey (ed.) (2013). Levinas Studies. An Annual Review, Vol. 8, Duquesne University Press, Pennsilvania.

Bloechl, Jeffrey (ed.) (2009). Levinas Studies. An Annual Review, Vol. 4, Duquesne University Press, Pennsilvania.

Brentano, Franz (1988). Philosophical Investigations on Space, Time and the Continuum. Routledge, London.

Buber, M. (2003): Eclipse de Dios. Fondo de Culturas Económica, México.

Calcagno, Antonio (2016). Edith Stein: Women, Social-Political Philosophy, Theology, Metaphysics, and Public History, New approaches and applications. Springer, Canada.

David, Katherine; Garffit, Toby (2014). God's Mirror: Renewal and Engagement in Frensh Catholic Intellectual Culture in the Mid-Twentieth Century. Fordham University Press, UK. 
86 | Veritas | Porto Alegre, v. 63, n. 1, jan-mar. 2018, p. 72-86

Domínguez, Xose; Calvo, Antonio; Narvarte, Luis (2002). La revolución personalista y comunitaria en Mounier. KADMOS, Salamanca.

Guevara, Ernesto (1985). Pasajes de la Guerra. Editorial de Ciencias Sociales, Cuba.

Lenin, Vladimir (1979). Obras Escogidas, tomo I. Editorial Progreso, Moscú.

Levinas, Emmanuel (1999). Alterity and Transcendence. Columbia University Press, New York.

Levinas, Emmanuel (1991). Entre nours. Essais sur le penser-a-l'autre. Grasset, France.

Levinas, Emmanuel (1990). Difficult Freedom, Essays on Judaism. The John Hopkins University Press, Baltimore.

Levinas, Emmanuel (1985). Ethics and Infinity. Duquesne University Press, Pennsilvania.

Levinas, Emmanuel (1982). Collected Philosophical Papers. Trad. Alphonso Lingis. Martinus Nijhoff Publishers, Boston.

Levinas, Emmanuel (1979). Le temps et l'autre. Fata Moraga, France.

Levinas, Emmanuel (1978). Autrement qu'etre ou au-dela de l'essence. Martinus Nijhoff, France.

Levinas, Emmanuel (1971). Totalite et infini. Martinus Nijhoff, France.

Morgan, Michael (2016). Levinas's Ethical Politics. Indiana University Press, Indiana.

Mounier, Emmanuel (2007). El compromiso de la acción. Fundación Emmanuel Mounier, Salamanca.

Mounier, Emmanuel (1990). ¿Qué es el personalismo? Obras completas. Tomo III. Sígueme, Salamanca.

Patocka, Ian (2005). Introducción a la fenomenología. Herder, España.

Romano, Claude (2015). At the Heart of Reason. Northwestern University Press, Illinois.

\section{Endereço Postal}

Instituto de Investigaciones en Filosofía Judía, Costa Rica

AP. 1825-2050 / Montes de Oca 11501 Costa Rica

Data de recebimento: $24 / 10 / 2017$

Data de aceite: 10/03/2018 